\title{
Independent Community Improvement to Manage Family Finances in Supporting OJK Programs
}

\author{
Khoirul Aswar, Ermawati, and Mahendro Sumardjo
}

\section{ABSTRACT}

\begin{abstract}
Financial control or management is quite important in reducing the gap between the rich and the poor. However, understanding related to family financial management is still quite low. The low level of community soft skills makes it less efficient in family management. This will have a negative impact on family management which will experience a deficit and make financial managers, in this case, housewives, often get into debt in several places. In addition, this service aims to support government programs through the Financial Services Authority (OJK) in family financial planning by providing assistance to housewives living in Unyur. The implementation method in the program uses training and mentoring on family financial management. The results of this dedication show that housewives are very enthusiastic about participating in the financial management training being held. So, housewives are able to manage household finances with programs launched by the government.
\end{abstract}

Keywords: Financial control, Financial Management, OJK programs, Soft skill, family finances.

\author{
Submitted : May 19, 2021 \\ Published : June 10, 2021 \\ ISSN: 2507-1076 \\ DOI: $10.24018 / \mathrm{ejbmr} .2021 .6 .3 .892$ \\ Khoirul Aswar* \\ University of Pembangunan Nasional \\ Veteran, Jakarta, Indonesia. \\ (e-mail: khoirulaswar@upnvj.ac.id) \\ Ermawati \\ University of Pembangunan Nasional \\ Veteran, Jakarta, Indonesia. \\ (e-mail: ermawati@upnvj.ac.id) \\ Mahendro Sumardjo \\ University of Pembangunan Nasional \\ Veteran, Jakarta, Indonesia. \\ (e-mail: sumardjo@yahoo.com) \\ *Corresponding Author
}

\section{INTRODUCTION}

The Rau wholesale market, the ancient market, and the royal area all reflect Serang city's advanced economic expansion as a result of the city's quick trade. One of the traditional food processing industries in the village of Kelanggaran Unyur, Serang City, such as glutinous rice opak, rengginang, gipang, melinjo chips, and fish meatball crackers, is still growing and thriving [1]. This can be seen in the growing number of craftsmen in the area who process specialty items. Because it is increasingly recognized by people in and outside the city of Serang, this typical food processed for present conditions has the potential to become better and larger. [2].

Government in Indonesia consists of several levels starting from the level of neighborhood, community, sub-district, district/city, provincial to national level. The condition of the government structure that is so long has certainly caused various kinds of polemics, ranging from the difficulty of managing each institution in detail to the slow delivery of information to the lowest line of government, namely the family.

Bank Indonesia [3] defines financial management as an action to achieve financial goals in the future. Financial management includes managing personal finances, managing family finances, and managing company finances. Family financial management has a significant role for household harmony. There are many things that must be considered so that household finances can run well and be the most beautiful from moneylenders. One of the things that must be considered is the management of family finances.

According to Bank Indonesia [3] there are steps in family financial management consisting of recording assets /assets owned, recording all income and expenditure, identifying routine, monthly and annual expenses for each person or family, and preparing periodic expenditure and saving plans.

The problems related to family financial management in Kelanggaran Unyur vary, this allows for conflict and also high social inequality. Financial control or management is quite important in reducing the gap so that the rich and the poor are not so conspicuous. However, the understanding regarding family financial management is still quite low. Many families think that family financial management is not an important thing so that housewives who act as family financial managers often experience confusion at the end of the month. This confusion is caused by the depletion of the family's money so that they cannot even save money. Human Resources (HR) development must also be prioritized in order to achieve the quality of society. This is in accordance with [4] states that community development must be carried out for the sake of improving the quality of society. The low level of community soft skills makes financial management less efficient in the family. This of course will have a negative impact on family management that will experience a deficit. In addition, financial management activities, in this case housewives, are often in debt in several places [5].

Referring to these conditions, Universitas Pembangunan Nasional Veteran Jakarta, which is a conservation university and is located adjacent to the area, has a big responsibility in 
order to improve the above conditions and care about the development of its surroundings. This family financial management training program will be more focused on developing the ability of household heads or mothers as family financial holders to be able to manage family finances so that they can be more prosperous. Furthermore, the formulation of the problem in this service activity is how to make women managing household finances able to manage their finances well, so that they can set aside their money to save for a better future.

\section{IMPLEMENTATION METHOD}

The participatory follow-up evaluation approach is used in the program's implementation method for IbM partners. This approach is used because it is necessary to conduct a partner situation analysis stage in the form of a field visit to the partners in order to tackle the challenges that housewives encounter as partners through a series of activities. Therefore, the methods used are lectures, question and answer, discussion and practice.

The implementation of this Community Service is carried out using the lecture, tutorial and discussion method. Furthermore, problem-solving methods to achieve the objectives of this activity are as follows:

a. methods of delivery or consolidation with residents consisting of sub-district officials, housewives.

b. Implementation of service activities which consisting: outreach activities to residents on the importance of family financial management and Family financial management training for housewives.

c. The material that will be given to participants in this activity is an explanation of the following: the importance of family financial management, procedures for recording transactions in family financial management, and how to carry out financial management appropriately and efficiently.

d. Monitoring of activities that have been carried out. Monitoring is carried out by asking mothers who participated in the training regarding difficulties found in implementing the training program. Furthermore, from the difficulties encountered, the servant formulates a solution to solve these difficulties.

e. Evaluation. Evaluation is carried out to determine the success of this activity which can be seen from the following indicators: Implementation of family financial management training programs, implemented family financial management assistance, Housewives are able to carry out family financial management appropriately and efficiently to improve family welfare.

\section{RESULTS AND DISCUSSION}

Indicators of the success of Community Service activities in addition to the high level of satisfaction. In addition, it can also be seen from the evaluation of the suitability of community service activities with the needs of the target community. The hope of the UPNVJ community service team with the dissemination of understanding on Institutional Strengthening can provide knowledge and understanding.
Responses related to the implementation of needs conformity obtained by the percentage of housewives' participants in the partner needs suitability category of $92.80 \%$ which stated that they were very suitable and $7.20 \%$ stated that they were appropriate. These results indicate that the community service participants stated that the activity materials provided were in accordance with the needs of housewives in Kelanggaran Unyur.

This community service activity has been successfully carried out. Housewives are able to carry out family financial management appropriately and efficiently. Furthermore, thanks to this dedication, housewives have learned to understand the Financial Services Authority (OJK) program in managing family finances. In addition, this program is able to improve the quality of human resources in managing household finances. In addition, it also increases understanding and quality to the community, especially housewives, of the importance of managing their household finances.

Family financial management activities in the context of enhancing independent communities and playing a role in improving Indonesian financial literacy have been running smoothly. this service is the stage where the service team provides an introduction to the material for financial credit debits and how to do simple recording. Mothers were taught simple methods of managing finances appropriately and easily. Furthermore, in this session, monitoring, evaluation and ensuring that mothers fully understand the implementation of good financial management.

As for the evaluation of material delivery. The knowledge of mothers related to household financial management before the training was carried out was still lacking and after the implementation of this activity there was an increase in results, as a result, it can be said that the service team's material delivery was as predicted. Meanwhile, those who said it were very good were $95 \%$, who said they were good at $5 \%$.

Based on the dedication that has been done, it shows that mothers are very enthusiastic about managing family finances for the better. Furthermore, this activity makes mothers aware of the importance of managing household finances in an orderly and disciplined manner.

\section{CONCLUSION AND RECOMMENDATION}

Based on the dedication that has been done, it can be concluded that the service activities have run smoothly and the community has gained an understanding related to financial management from the service team. Furthermore, this activity is expected to be able to improve the ability of housewives in managing household finances. There are suggestions that can be recommended, namely the need for further assistance to housewives related to financial management. Mothers who are the cornerstones of creating the younger generation need to be constantly encouraged and their abilities in order to build a prosperous family. Furthermore, it is still necessary to provide trainings that can stimulate housewives' enthusiasm to earn additional income for the sake of improving family welfare. 
European Journal of Business and Management Research www.ejbmr.org

\section{REFERENCES}

[1] Aswar, K., \& Ermawati, E. (2019). Peningkatan Keterampilan penyusunan laporan keuangan bagi kelompok usaha mikro makanan khas daerah kota Serang. Sabdamas, 1(1), 96-100.

[2] Aswar, K., \& Ermawati, E. (2020). Determination of cost of sales and utilization of internet media for SMEs Marketing in Kelanggaran Unyur. European Journal of Business and Management Research. 5(5), 1-3.

[3] Bank Indonesia. (2015). Pengelolaan keuangan. grup pengembangan keuangan insklusif departement pengembangan akses keuangan dan umkm bank Indonesia. Jakarta.

[4] Ife, J. (1995). Community development (creating community alternatives, vision, analysis and practice). Melbourne Australia: Longman Australia Pty Ltd.

[5] Sukirman, S., Hidayah, R., Syrtabdari, D., \& Purwanti, A. (2019). Pengelolaan keuangan keluarga dalam rangka peningkatan masyrakat mandiri dan berperan dalam peningkatan literasi kauangan Indonesia (Otoritas Jasa Keuangan). Jurnal Pengabdian Kepada Masyarakat. 23(2), 165-169. 